Postgraduate Bosowa University Publishing (PBUP)
Indonesian Journal of Business and Management
e-ISSN: $2460-3767 \quad p$-ISSN: $2656-6885$
Pttps://postgraduate.universitasbosowa.ac.id/index.php/jbm

\title{
PENGARUH KOMPETENSI, KOMITMEN ORGANISAS DAN INDEPENDENS TERHADAP KINERJA AUDITOR PADA INSPEKTORAT PROVINS SULAWES BARAT
}

\author{
The Influence of Competency, Organizational Commitment and Independence on Auditor Performance \\ in Inspectorate of West Sulawes Province
}

\author{
Andi Mansahid Priogandi ${ }^{1}$, Firman Menne ${ }^{2}$, Herminawat Abubakar ${ }^{3}$ \\ ${ }^{1}$ Mahasiswa Magister Manajemen Universitas Universitas Bosowa \\ ${ }^{2}$ Program Stud Manajemen Program Pascasarjana Universitas Bosowa \\ Email: andiyoyo51@gmail.com
}

Diterima: 22 Januar 2021/Disetujui: 02 Jun 2021

\begin{abstract}
ABSTRAK
Penelitian in bertujuan untuk mengetahu dan meng-analisis pengaruh kompetensi, komitmen organisas dan independens terhadap kinerja auditor pada Inspektorat Provins Sulawes Barat. Teknik pengumpulan data melalu kuesioner, observasi, wawancara dan telaah dokumen. Sedangkan teknik analisis data yang diguna-kan adalah uj kualitas data, uj asums klasik, analisis regres linear berganda, pengujian hipotesis, dan koefisien determinasi. Berdasarkan hasil analisis maka diperoleh hasil bahwa kompetens mempunya pengaruh yang positif dan signi-fikan terhadap kinerja auditor pada Kantor Inspektorat Provins Sulawes Barat. Komitmen Organisas mem-punya pengaruh yang positif dan signifikan terhadap kinerja auditor pada Kantor Inspektorat Provins Sulawes Barat. Independens mempunya pengaruh yang positif dan signifikan terhadap kinerja auditor pada Kantor Inspektorat Provins Sulawes Barat. Hasil peng-ujian serempak maka dapat disimpulkan bahwa kompetensi, komitmen organisasi, dan independens mempunya pengaruh secara serempak atau bersama-sama terhadap kinerja auditor pada Kantor Inspektorat Provins Sulawes Barat. Dar hasil pengujian regres maka diketahu bahwa variabel yang dominan berpengaruh terhadap kinerja auditor pada Kantor Inspektorat Provins Sulawes Barat adalah komitmen organisasi.
\end{abstract}

Kata Kunci: Kompetensi, Komitmen Organisasi, Independens Dan Kinerja Auditor

\begin{abstract}
This study aims to determine and analyze the influence of competence, organizational commitment and independence on auditor performance at the Inspectorate of West Sulawes Province. Data were collected through questionnaires, observation, interviews and document reviews. Meanwhile, the data analysis techniques used are data quality test, classical assumption test, multiple linear regression analysis, hypothesis testing, and the coefficient of determination. Based on the analysis, the results show that competence has a positive and significant effect on the performance of auditors at the Inspectorate Office of West Sulawes Province. Organizational commitment has a positive and significant effect on auditor performance at the Inspectorate Office of West Sulawes Province. Independence has a positive and significant effect on auditor performance at the Inspectorate Office of West Sulawes Province. From the results of simultaneous testing, it can be concluded that competence, organizational commitment, and independence have a simultaneous or joint effect on the performance of auditors at the Inspectorate Office of West Sulawes Province. From the results of regression testing, it is known that the dominant variable affecting the performance of auditors at the Inspectorate Office of West Sulawes Province is organizational commitment.
\end{abstract}

Keywords: Competence, Organizational Commitment, Independence

\section{PENDAHULUAN}

Dewasa ini tuntutan masyarakat akan penyelenggaraan pemerintahan yang bersih, adil, transparansi dan akuntabel saat in semakin meningkat. Upaya dalam melayan tuntutan masyarakat maka kegiatan yang harus dilakukan pemerintah saat in adalah 
meningkatkan good governane yang baik, dengan cara menetapkan sasaran untuk meningkatkan pelayanan bikroras kepada masyarakat dengan arah kebijakan penciptaan tata pemerintahan yang bersih dan berwibawa.

Dengan adanya komitmen pemerintah untuk mewujudkan good governance khususnya pemberantasan korupsi, kolus dan nepotisme, maka kinerja atas penyelenggaraan organisas pemerintah menjad perhatian pemerintah untuk dibenahi, salah satunya melalu sistem pengawasan yang efektif, dengan meningkatnya peran dan fungs dar aparat intern pemerintah (APIP). Sebaga aparat pengawasan intern pemerintah, inspektorat pemerintah daerah memilik peran dan posisi strategis, baik ditinjau dari aspek fungsi manajemen maupun dari segi pencapaian visi dan misi serta program program pemerintah.Dari segi fungsi fungsi dasar manajemen memiliki kedudukan yang setara dengan fungsi perencanaan atau fungsi pelaksanaan dan dari segi pencapaian visi,misi dan program pemerintah. (Yasa, 2016) .

Pentingnya fungsi dan peran inspektorat dalam melakukan pengawasan intern pemerintah, maka sangatlah diperlukan adanya kinerja aparat intern pemerintah dalam melaksanakan aktivitasnya. Kinerja adalah merupakan implementasi dari rencana yang telah disusun tersebut. Implementasi kinerja dilakukan oleh sumber daya manusia yang memiliki kemampuan kompetensi, motivasi dan kepentingan, bagaimana organisasi menghargai dan memperlakukan sumber daya manusianya akan mempengruhi sikap dan perilakunya dalam menjalankan kinerjanya. (Wibowo, 2017)

Kinerja merupakan hal yang sangat penting bagi suatu organisasi, oleh karena itu suatu organisasi publik, khususnya sebagai tenaga pemeriksa keuangan publik (Auditor sektor publik) perlu memiliki kinerja dari pelaksanaan atas pekerjaaanya. Menurut Rismawati dan Bachtiar (2014) bahwa kinerja auditor merupakan tindakan atau pelaksanaan tugas pemeriksaan yang telah diselesaikan oleh auditor dalam kurun waktu tertentu, sehingga dalam meningkatkan kinerja auditor maka terdapat sejumlah faktor yang mempengaruhi kinerja auditor yaitu independensi, kompentensi dan komitmen organisasi.

Masalah independensi sebagai sikap seseorang untuk bertindak jujur, tidak memihak dan melaporkan temuan temuan hanya berdasarkan bukti yang ada. Disamping itu dengan adanya kode etik, masyarakat akan dapat menilai sejauh mana auditor telah bekerja sesuai dengan standar etika yang telah ditetapkan oleh profesinya. (Istiariani, 2018). Kemudian Trisnaningsih (2017) bahwa pemahaman good governance dapat meningkatkan kinerja auditor, jika auditor tersebut selama dalam pemeriksaan selalu menegakkan sikap independensi. Sehingga dapat dikatakan bahwa independensi mempengaruhi kinerja auditor.

Faktor lainnya yang mempengaruhi kinerja auditor adalah kompetensi, penentuan kompetensi dibutuhakan agar dapat mengetahui tingkat prestasi yang diharapkan untuk kategori baik atau rata- rata dan penentuan kompetensi yang dibutuhkan tentunya akan dapat dijadikan dasar bagi pihak evaluasi prestasi kerja (Sutrisno, 2017). Sedangkan menurut Busro (2019) bahwa kompetensi adalah segala sesuatu yang dmiliki oleh seseorang berupa pengetahuan, ketrampilan dan faktor faktor internal individu lainnya untuk dapat mengerjakan sesuatu pekerjaan berdasarkan pengetahuan dan ketrampilan yang harus dimiliki.

Kemudian Bagia (2015) yang mengemukakan bahwa komitmen itu merupakan perwujudan dari kerelaan seseorang dalam bentuk pengikatan diri dengan diri sendiri (individu) atau dengan organisasi yang digambarkan oleh besarnya usaha (tenaga, waktu dan pikiran) untuk mencapai tujuan pribadi dari visi bersama. Sehingga dapat dikatakan bahwa semakin tinggi tingkat komitmen karyawan maka akan semakin lama ia ingin tetap berada dalam organisasi dan semakin tinggi pula produktivitasnya kepada organisasi dan tingkat keluar masuknya karyawan akan semakin rendah, Sedangkan menurut Sopiah (2008) bahwa komitmen organisasional pimpinan, baik yang tinggi maupun yang rendah akan berdampak terhadap karyawan, misalnya terhadap perkembangan kiinerja dan karier pegawai pada organisasi. Organisasi, pimpinan yang berkomitmen tinggi pada organisasi akan menimbulkan kinerja organisasi yang tinggi, tingkat absensi, loyalitas karyawan, dari pendapat yang dikemukakan oleh Bagia (2015) dan Sopiah (2008) maka dapat dikatakan bahwa komitmen organisasi akan dapat memberikan pengaruh dalam meningkatkan kinerja kerja.

Adapun obyek dalam penelitian ini adalah pada Kantor Inspektorat di provinsi Sulawesi Barat, yang menjadi visinya adalah terwujudnya pemerintahan Provinsi Sulawesi Barat yang maju dan malaqbi melalui pengawasan internal yang profesional. Sedangkan misinya adalah mendong peningkatkan kapabilitas APIP, mendorong penguatan sistem pengendalian intern pemerintah dan mendorong penguatan peran inspektorat sebagai quality assuranse. Dar hasil pengamatan dalam lingkup kantor Inspektorat, Provins Sulawes Barat bahwa kinerja auditor yang terjad selama in masih kurang optimal, hal in disebabkan karena lambatnya pelaporan LHP oleh auditor sebab tingkat pekerjaan oleh auditor (APIP) mengalam keterlambatan. Hal in terjad karena informas yang diperlukan oleh auditor (APIP) saat melakukan pemeriksaan mengalam keterlambatan dan selain itu masih banyaknya tekanan tekanan dar pihak yang berkepentingan kepada auditor (APIP) saat melakukan pelaporan LHP. Sehingga dengan riset gap dan fenomena yang ditemukan oleh penelit saat melakukan survey d kantor inspektorat maka hal in yang menjad alasan perlunya menelit mengena faktor independensi, kompetens dan komitmen organisas terhadap kinerja auditor pada kantor Inspektorat Provins Sulawes Barat. 


\section{METODE}

a. Jenis Penelitian

Jenis penelitian yang digunakan adalah jenis penelitian kuantitatif. Penelitian kuantitatif adalah penelitian yang secara primer menggunakan paradigma postpositivist dalam mengembangkan ilmu pengetahuan (seperti pemikiran tentang sebab akibat, reduksi kepada variabel, hipotesis, pertanyaan spesifik, menggunakan pengukuran dan observasi, serta pengujian teori) menggunakan strategi penelitian seperti eksperimen dan survei yang memerlukan data statistik. Penelitian ini menggunakan pendekatan Regresi Analysis dan deskriptif analitis, yang bertujuan untuk menjelaskan hubungan dan pengaruh antara variabel bebas dan terikat. Adapun jenis penelitian yang digunakan dalam penelitian ini adalah penelitian eksplanatori yaitu penelitian yang berusaha menjelaskan pola hubungan antara variabel-variabel yang digunakan dalam penelitian dan menguji hipotesis yang telah dirumuskan. Variabel dalam penelitian ini terdiri atas variabel bebas dan variabel terikat. Variabel bebas adalah kompetensi $\left(\mathrm{X}_{1}\right)$, Komitmen Organisasi $\left(\mathrm{X}_{2}\right)$, dan Independensi $\left(\mathrm{X}_{3}\right)$ Variabel terikat adalah Kinerja auditor (Y).

b. Lokasi Penelitian

Penelitian ini dilaksanakan pada Kantor Inspektorat Sulawesi Barat berlokasi di Jalan H. Abd. Malik Pattana Endeng Ragas Kompleks Perkantoran Gubernur Sulawesi Barat.

c. Populasi dan Sampel

Populasi menurut Sangadji dan Sopiah (2013) adalah wilayah generalisasi yang terdiri atas subyek atau obyek dengan kualitas dan karakteristik tertentu yang ditetapkan oleh peneliti untuk dipelajari dan kemudian ditarik kesimpulan. Mengacu dari teori tersebut maka yang menjadi populasi dalam penelitian ini adalah auditor yang bekerja pada Inspektorat Provinsi Sulawesi Barat sebanyak 40 orang. Sampel adalah bagian dari jumlah dan karakteristik yang dimiliki oleh populasi, dimana jumlah sampel dalam penelitian ini adalah sebanyak 40 orang auditor yang bekerja di Inspektorat Provinsi Sulawesi Barat.

Teknik penarikan sampel dengan menggunakan metode non probability sampling, dimana menurut Sangadji dan Sopiah (2013) yakni pengambilan sampel yang tidak memberi peluang atau kesempatan sama bagi setiap unsur atau anggota populasi untuk dipilih menjadi sampel, sedangkan teknik penarikan sampel dengan menggunakan sampling jenuh yakni teknik penentuan sampel bila semua anggota populasi digunakan sebagai sampel, sehingga mengacu dari uraian tersebut maka sampel yang dipilih adalah keseluruhan jumlah populasi yang ada yakni sebanyak 40 orang auditor Inspektorat Provinsi Sulawesi Barat.

d. Variabel Penelitian

Dalam setiap penelitian, biasanya apa yang akan diteliti itu disebut dengan variabel penelitian. Variabel penelitian adalah segala sesuatu yang akan menjadi objek pengamatan penelitian. Pengertian yang dapat diambil dari definisi tersebut ialah bahwa dalam penelitian terdapat sesuatu yang menjadi sasaran, yaitu variabel, sehingga variabel merupakan fenomena yang menjadi pusat perhatian penelitian untuk diobservasi atau diukur.

Sesuai dengan judul penelitian yang dipilih peneliti yaitu Pengaruh kompetensi, Komitmen organisasi dan independensi terhadap kinerja auditor internal pada Inspektorat Provinsi Sulawesi Barat, maka variabelvariabel dalam judul penelitian dikelompokkan ke dalam 2 (dua) macam variabel, yakni diantaranya: 1. Variabel Independen, (Kompetensi, Komitmen Organisasi dan Independensi), dan 2. Variabel Dependen (Kinerja auditor Y)

e. Teknik Pengumpulan Data

Dalam penelitian ini, peneliti menggunakan

beberapa tehnik pengumpulan data yaitu :

1. Kuesioner

Kuesioner yakni teknik pengumpulan data dengan menyebarkan sejumlah angket atau pertanyaan kepada responden, dengan harapan mereka akan memberikan respon atas pertanyaan dalam bentuk kuesioner yang telah disebarkan untuk diisi kepada responden

2. Pengamatan Langsung

Pengamatan Langsung yaitu teknik penelitian yang dilakukan dengan mengadakan pengamatan atau peninjauan secara langsung pada lokasi penelitian. Hal ini dimaksudkan untuk memperoleh data di lapangan.

3. Wawancara

Teknik pengumpulan data yang dilakukan oleh peneliti melalui tanya jawab atau tatap muka secara langsung dengan beberapa orang informan yang dianggap memiliki pengetahuan yang memadai tentang masalah yang diteliti.

4. Telaah Dokumen

Telaah dokumen yaitu tehnik pengumpulan data yang dilakukan dengan cara mengumpulkan sejumah data-data tertulis, dokumen-dokumen penting baik yang berasal dari Inspektorat Provinsi Sulawesi Barat maupun yang berasal dari sejumlah literatur dan bahan pustaka.

f. Jenis dan Sumber Data

Adapun jenis data yang digunakan dalam penelitian ini adalah :

a. Data kualitatif

Data kualitatif yaitu data yang diperoleh berupa keterangan-keterangan tertulis yang mendukung penelitian ini, seperti: Gambaran umum Kantor Inspektorat Provinsi Sulawesi Barat, Struktur organisasi dan uraian tugas masing-masing bagian.

b. Data kuantitatif

Data kuantitatif yaitu data yang berupa angka-angka yang dapat dihitung, seperti jumlah auditor serta data-data numerik lainnya baik yang telah diolah maupun belum diolah yang mendukung penelitian ini. 
Sedangkan sumber data diperoleh dari.

a. Data primer

Pengumpulan data primer dilakukan melalui kuesioner merupakan salah satu cara untuk mendapatkan data. Kuesioner disebarkan secara langsung ke Kantor Inspektorat Provinsi Sulawesi Barat tempat para auditor melakukan pemeriksaan.

b. Data sekunder

Data sekunder yaitu data yang diilakukan dengan cara mengumpulkan data dari bahanbahan atau sumber-sumber bacaan atau kepustakaan. Pengumpulan data sekunder ini dimaksudkan untuk melengkapi data dari berbagai sumber antara lain : Buku-buku, literatur, Internet, bahan kuliah dan literatur lainnya yang ada hubungannya dengan penelitian ini.

g. Teknis Analisis Data

Metode analisis data adalah proses penyederhanaan data kedalam bentuk yang lebih mudah dibaca dan diinterprestasikan. Metode yang dipilih untuk analisis data harus sesuai dengan pola penelitian dan variabel yang akan diteliti. Adapun metode analisis yang digunakan adalah :

1. Uji Kualitas Data

a. Uji validitas

Uji validitas dan reliabilitas kuesioner dilakukan untuk menguji apakah suatu pertanyaan (kuesioner) layak digunakan sebagai instrument penelitian. Valid berarti instrumen tersebut dapat digunakan untuk mengukur apa yang seharusnya diukur. Validitas berhubungan dengan ketepatan alat ukur melakukan tugasnya mencapai sasaran. Pengukuran dikatakan valid jika mengukur tujuannya dengan nyata dan benar.

b. Uji Reliabilitas

Reliabilitas menunjukkan akurasi dan konsistensi dari pengukurannya. Dikatakan konsisten jika beberapa pengukuran terhadap subyek yang sama diperoleh hasil yang tidak berbeda Sugiyono, (2016:352). Reliabel artinya data yang diperoleh melalui kuesioner hasilnya konsisten. Uji validitas dan reliabilitas kuesioner penelitian ini menggunakan bantuan software SPSS 25.0 for windows.

2. Uji Asumsi Klasik

Sebelum melakukan analisis regresi, agar dapat perkiraan yang tidak bias dan efisiensi maka dilakukan pengujian asumsi klasik yang harus dipenuhi, yaitu :

a. Uji Normalitas

Tujuan uji normalitas adalah untuk mengetahui apakah distribusi sebuah data mengikuti atau mendekati distribusi normal. Uji normalitas dilakukan dengan menggunakan pendekatan Kolmogrov Smirnov. Dengan menggunakan tingkat signifikan 5\% maka jika nilai Asymp.sig. (2-tailed) di atas nilai signifikan 5\% artinya variabel residual berdistribusi normal (Situmorang dkk 2011). b. Uji Heteroskedastisitas

Adanya varians variabel independen adalah konstan untuk setiap nilai tertentu variabel independen (homokedastisitas). Model regresi yang baik adalah tidak terjadi heteroskedatisitas. Heteroskedastisitas diuji dengan menggunakan uji Glejser dengan pengambilan keputusan jika variabel independen signifikan secara statistik mempengaruhi variabel dependen, maka ada indikasi terjadinya heteroskedastisitas. Jika probabilitas signifikannya di atas tingkat kepercayaan 5\% dapat disimpulkan model regresi tidak mengarah adanya heteroskedastisitas.

c. Uji Multikolinearitas

Artinya variabel independen yang satu dengan yang lain dalam model regresi berganda tidak saling berhubungan secara sempurna. Untuk mengetahui ada tidaknya gejala multikolinearitas dapat dilihat dari besarnya nilai Tolerance dan VIF (Variance Inflation Factor) melalui program SPSS. Tolerance mengukur variabilitas variabel terpilih yang tidak dijelaskan oleh variabel independen lainnya. Nilai umum yang biasa dipakai adalah nilai Tolerance $>1$ atau nilai VIF $<5$, maka tidak terjadi multikolinearitas (Situmorang dkk 2011).

3. Analisis Regresi Linear Berganda

Untuk menguji pengaruh antara variabel kompetensi, komitmen organisasi dan independensi terhadap kinerja auditor dengan menggunakan analisis regresi linear berganda berdasarkan rumus yang dikemukakan oleh Sujarweni (2016: 108) yaitu : $\mathrm{Y}=\beta \mathrm{o}+\beta_{1} \mathrm{x}_{1}+\beta_{2} \mathrm{x}_{2}+\beta_{3} \mathrm{x}_{3}+\dot{\varepsilon}$

4. Pengujian Hipotesis

Pengujian hipotesis dapat dilakukan dengan dua cara yaitu uji t (uji parsial) dan uji f (uji serempak) yang dapat diuraikan sebagai berikut :

a. Uji T

Uji t dilakukan untuk mengetagui pengaruh masingmasing variabel independent secara parsial terhadap variabel dependen. Uji $t$ dilakukan dengan membandingkan nilai probabilitas dan nilai standar.

b. Uji F

Pengujian ini dilakukan untuk mengetahui apakah semua variabel independent secara bersama-sama dapat berpengaruh terhadap variabel dependen. Cara yang digunakan adalah dengan membanding-kan nilai nilai $\mathrm{F}_{\text {hitung }}$ dengan nilai $\mathrm{F}_{\text {tabel. }}$

5. Koefisien Determinasi. $\left(\mathrm{R}_{2}\right)$

Koefisien determinasi $\left(\mathrm{R}^{2}\right)$ pada intinya mengukur seberapa jauh kemampuan model dalam menerapkan variabel-variabel dependen. Nilai koefisien determinasi adalah antara moldan satu. Nilai $\mathrm{R}^{2}$ yang kecil berarti kemampuan variabel-variabel independen dalam menjelaskan variabel-variabel dependen amat terbatas. Nilai yang mendekati satu berarti variabel-variabel independen memberikan hampir semua informasi yang 
dibutuhkan untuk memprediksi variabel-variabel dependen. (Ghosali 2018)

\section{HASIL DAN PEMBAHASAN}

Analisis statistik inferensial yang digunakan dalam penelitian ini adalah analisis regresi linier berganda. Analisis ini bertujuan untuk mengukur besarnya pengaruh antara dua variabel dependen atau lebih dan memprediksi variabel dependen dengan menggunakan variabel independen. Secara ringkas hasil uji regresi linear berganda dapat dilihat pada tabel sebagai berikut:

Tabel 1. Analisis Regresi Linear Berganda

\begin{tabular}{|c|c|c|c|c|c|c|}
\hline \multirow{2}{*}{\multicolumn{2}{|c|}{ Model }} & \multicolumn{2}{|c|}{$\begin{array}{l}\text { Unstandardized } \\
\text { Coefficients }\end{array}$} & \multirow{2}{*}{$\begin{array}{l}\text { Stdz } \\
\text { Beta }\end{array}$} & \multirow[b]{2}{*}{$\mathrm{t}$} & \multirow[b]{2}{*}{ Sig. } \\
\hline & & $\mathrm{B}$ & $\begin{array}{l}\text { Std. } \\
\text { Error }\end{array}$ & & & \\
\hline \multirow[t]{4}{*}{1} & (Constant) & .209 & .677 & & .309 & .759 \\
\hline & Kompetensi & .318 & .101 & .382 & 3.151 & .003 \\
\hline & $\begin{array}{l}\text { Komitmen } \\
\text { Organisasi }\end{array}$ & .378 & .112 & .399 & 3.372 & .002 \\
\hline & Independensi & .319 & .101 & .382 & 3.155 & .003 \\
\hline
\end{tabular}

Dari tabel persamaan regresi linear berganda maka dapat disajikan hasil persamaan sebagai sebagai berikut :

$$
\begin{aligned}
& \mathrm{Y}=\mathrm{b}_{0}+\mathrm{b}_{1} \mathrm{X}_{1}+\mathrm{b}_{2} \mathrm{X}_{2}+\mathrm{b}_{3} \mathrm{X}_{3} \\
& \mathrm{Y}=0,209+0,382 \mathrm{X}_{1}+0,399 \mathrm{X}_{2}+0,382 \mathrm{X}_{3}
\end{aligned}
$$

Penjelasan dari persamaan fungsi regresi linear berganda di atas adalah :

a) Nilai koefisien regresi variabel kompetensi sebesar 0,382 . Artinya bahwa kompetensi berpengaruh positif terhadap kinerja auditor pada Inspektorat Provinsi Sulawesi Barat, yang artinya semakin tinggi kompetensi yang dimiliki maka kinerja auditor akan semakin meningkat.

b) Nilai koefisien regresi variabel komitmen organisasi sebesar 0,399. Artinya bahwa komitmen organisasi berpengaruh positif terhadap kinerja auditor pada Inspektorat Provinsi Sulawesi Barat, hal ini berarti bahwa apabila komitmen organisasi ditingkatkan maka akan mempengaruhi kenaikan kinerja auditor.

c) Nilai koefisien regresi variabel independensi sebesar 0,382 , yang berarti bahwa independensi berpengaruh positif terhadap kinerja auditor pada Inspektorat Provinsi Sulawesi Barat, ini menunjukkan bahwa semakin tinggi independensi auditor maka kinerja auditor akan semakin meningkat pula.

Kemudian untuk mengetahui hubungan antara variabel bebas (kompetensi, komitmen organisasi, independensi) terhadap variabel terikat (kinerja auditor) pada Kantor Inspektorat Provinsi Sulawesi Barat maka hasil perhitungan koefisien korelasi diperoleh nilai $\mathrm{R}=$ 0,706 , hal ini menunjukkan bahwa ketiga variabel bebas yakni kompetensi, komitmen organisasi, dan independensi memiliki hubungan yang kuat terhadap kinerja auditor, sebab nilai $\mathrm{R}$ positif dan mendekati 1 . Kemudian dari hasil uji determinasi (kehandalan model) memperlihatkan nilai adjusted Rsquare $=0,456$. Hal ini berarti bahwa sebesar 45,6\% variabel tidak bebas kinerja auditor dipengaruhi oleh kompetensi, komitmen organisasi, dan independensi, sedangkan sisanya sebesar $54,4 \%(1-0,456)$ dipengaruhi oleh variabel lain yang tidak dimasukkan dalam penelitian ini, seperti : disiplin kerja, diklat, kompensasi dan lain sebagainya.

Hasil pengujian hipotesis diklasifikasikan atas 2 yakni uji parsial (uji t) dan uji serempak (uji f), yang dapat diuraikan satu persatu sebagai berikut :

a) Uji Parsial (uji t)

Untuk mengetahui pengaruh secara parsial atau masing-masing variabel bebas terhadap variabel terikat maka digunakan uji parsial (uji t). Untuk mengetahui pengaruh tersebut, dapat dilakukan dengan cara

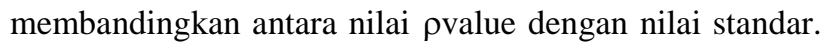
Apabila nilai pvalue lebih kecil dari nilai standar $(0,05)$ berarti memberikan pengaruh secara signifikan.

1) Pengaruh kompetensi terhadap kinerja auditor

Hasil analisis regresi linear berganda maka diperoleh nilai $\rho$ value untuk kompetensi sebesar 0,003 , karena nilai $\rho$ value $0,003<0,05$ (nilai standar) maka dapat dikatakan bahwa kompetensi mempunyai pengaruh signifikan terhadap kinerja auditor pada Inspektorat Provinsi Sulawesi Barat.

2) Pengaruh komitmen organisasi terhadap kinerja auditor

Hasil analisis regresi linear berganda maka diperoleh nilai $\rho$ value untuk komitmen organisasi sebesar 0,002 , karena nilai $\rho$ value $0,002<0,05$ (nilai standar) maka dapat dikatakan bahwa komitmen organisasi mempunyai pengaruh signifikan terhadap kinerja auditor pada Inspektorat Provinsi Sulawesi Barat.

3) Pengaruh independensi organisasi terhadap kinerja auditor

Hasil analisis regresi linear berganda maka diperoleh nilai $\rho$ value untuk independensi sebesar 0,003, karena nilai $\rho$ value $0,003<0,05$ (nilai standar) maka dapat dikatakan bahwa independensi mempunyai pengaruh signifikan terhadap kinerja auditor pada Inspektorat Provinsi Sulawesi Barat

b) Uji Serempak (Uji F)

Uji serempak (uji f) digunakan untuk mengetahui pengaruh secara serempak atau bersama-sama variabel bebas : kompetensi, komitmen organisasi, dan independensi terhadap variabel terikat kinerja auditor. Untuk pengujian ini dapat dilakukan dengan membandingkan antara nilai signifikan dengan nilai standar. Apabila nilai signifikan < dari nilai standar, berarti memberikan pengaruh secara serempak. Berdasarkan tabel ANOVA maka diperoleh nilai sig. 0,000 , karena nilai sig. lebih kecil dari nilai standar 0,05, maka sebagaimana dasar pengambilan keputusan dalam uji f, hal ini menunjukkan bahwa kompetensi, komitmen organisasi, dan independensi berpengaruh secara bersama-sama atau serempak terhadap kinerja auditor pada kantor Inspektorat Provinsi Sulawesi Barat. Dengan demikian dapat disimpulkan bahwa model yang dibangun cukup baik. 
1. Pengaruh Kompetensi Terhadap Kinerja Auditor

Berdasarkan hasil analisis persamaan regresi maka diperoleh hasil bahwa kompetensi mempunyai pengaruh yang positif dan signifikan terhadap kinerja auditor pada Inspektorat Provinsi Sulawesi Barat. Hal ini sesuai dengan teori yang dikemukakan oleh Sutrisno (2017:202) bahwa penentuan kompetensi dibutuhkan agar dapat mengetahui tingkat prestasi yang diharapkan untuk kategori baik atau rata rata dan penentuan kompetensi yang dibutuhkan tentunya akan dapat dijadikan dasar bagi pihak evaluasi prestasi kerja Sedangkan menurut Busro (2019:26) bahwa kompetensi adalah segala sesuatu yang dmiliki oleh seseorang berupa pengetahuan, ketrampilan dan faktor-faktor internal individu lainnya untuk dapat mengerjakan sesuatu pekerjaan berdasarkan pengetahuan dan ketrampilan yang harus dimiliki sehingga menghasilkan kinerja yang baik. Dari hasil penyebaran kuesioner maka diperoleh temuan empirik bahwa kompetensi yang dimiliki oleh auditor sudah tergolong tinggi, hal ini dapat dilihat bahwa setiap auditor sudah memiliki kemampuan kerja, hasil temuan bahwa rata-rata pegawai memiliki kemampuan dalam menyelesaikan pekerjaan sebagai auditor di kantor Inspektorat, serta setiap pegawai sudah memiliki kemampuan dalam berinteraksi dengan pihak lain dalam bidang pekerjaan audit.

Kemudian ditinjau dari pengalaman kerja, hasil temuan bahwa rata-rata pegawai sudah memiliki pengalaman kerja dalam bidang audit, karena dengan pengalaman yang dimiliki pegawai membantu dalam menyelesaikan tugasnya sebagau auditor, serta membantu auditor dalam mengurangi kesalahan dalam penanganan pekerjaan audit. Selanjutnya dilihat dari pelatihan, bahwa rata-rata pegawai aktif dalam mengikuti pelatihanpelatihan terkait bidang kerja serta materi pelatihan sesuai dengan pekerjaan yang ditangani. Begitu pula dilihat dari segi pengetahuan, nampak bahwa rata-rata pegawai memiliki pengetahuan dengan bidang pekerjaan sebagai tenaga pemeriksa serta tingkat pengetahuan yang dimiliki pegawai menunjang penyelesaian pekerjaan sebagai tenaga pemeriksa. Hasil temuan ini dapat disimpulkan bahwa dengan adanya kompetensi yang dimiliki oleh setiap pegawai melalui kemampuan, pengalaman kerja, pelatihan yang diselenggarakan serta pengetahuan yang dimiliki pegawai maka akan menjadi kompetensi yang dimiliki pegawai dalam menangani bidang kerja sebagai tenaga pemeriksa. Sehingga hal ini dapat dikatakan bahwa rata-rata auditor sudah memiliki kompetensi kerja yang tinggi karena pegawai sudah memiliki kemampuan, pengalaman kerja, pelatihan dan pengetahuan sehingga berpengaruh terhadap peningkatan kinerja auditor pada Kantor Inspektorat Provinsi Sulawesi Barat. Hasil penelitian yang peneliti lakukan sejalan dengan penelitian yang dilakukan oleh Awaluddin (2013), Istiariani (2018), Ningrum (2017) yang hasil penelitiannya menemukan bahwa kompetensi berpengaruh positif dan signifikan terhadap kinerja auditor.
2. Pengaruh Komitmen Organisasi terhadap Kinerja auditor

Dari hasil analisis persamaan regresi maka diperoleh hasil koefisien regresi bahwa komitmen organisasi mempunyai pengaruh yang positif dan signifikan terhadap kinerja auditor pada Inspektorat Provinsi Sulawesi Barat. Hal ini sejalan dengan teori yang dikemukakan oleh Bagia (2015:41) yang mengemukakan bahwa komitmen itu merupakan perwujudan dari kerelaan seseorang dalam bentuk pengikatan diri dengan diri sendiri (individu) atau dengan organisasi yang digambarkan oleh besarnya usaha (tenaga, waktu dan pikiran) untuk mencapai tujuan pribadi dari visi bersama. Sehingga dapat dikatakan bahwa semakin tinggi tingkat komitmen auditor maka akan semakin lama ia ingin tetap berada dalam organisasi dan semakin tinggi pula hasil prestasi kerja kepada organisasi. Hasil temuan empirik di lapangan bahwa komitmen organisasi yang ada pada Kantor Inspektorat Provinsi Sulawesi Barat termasuk dalam kategori baik. Ini dapat dilihat bahwa rata-rata auditor sudah memiliki komitmen afektif, dimana setiap pegawai memiliki perasaan bangga bekerja pada Kantor Inspektorat Provinsi Sulawesi Barat.

Ditinjau dari komitmen berkelanjutan, dimana dapat dilihat bahwa setiap pegawai berkeinginan bekerja karena adanya gaji yang sudah memenuhi kebutuhan keluarga, selanjutnya ditinjau dari komitmen normatif, terlihat bahwa setiap pegawai menyadari bahwa komitmen adalah merupakan hal yang penting bagi karir pegawai sebagai tenaga audit, begitu pula bahwa setiap pegawai berkeinginan menghabiskan sisa kair di kantor Inspektorat. Hal ini dapat disimpulkan bahwa semakin tinggi komitmen kerja yang dimiliki oleh pegawai maka kinerja kerja yang dicapai akan semakin tinggi dalam bidang pemeriksaan audit. Hasil penelitian ini sejalan dengan penelitian yang dilakukan oleh Ningrum (2017) bahwa komitmen organisasi berpengaruh positif dan signifikan terhadap kinerja auditor pemerintah, sedangkan penelitian Sujana (2012) bahwa komitmen organisasi berpengaruh secara signifikan terhadap kinerja.

3. Pengaruh Independensi Organisasi terhadap Kinerja auditor

Berdasarkan hasil analisis persamaan regresi maka diperoleh hasil koefisien regresi bahwa independensi mempunyai pengaruh yang positif dan signifikan terhadap kinerja auditor pada Inspektorat Provinsi Sulawesi Barat. Hal ini sejalan dengan teori yang dikemukakan oleh Istiariani (2018) bahwa independensi sebagai sikap seseorang untuk bertindak jujur, tidak memihak dan melaporkan temuan temuan hanya berdasarkan bukti yang ada. Disamping itu dengan adanya kode etik, masyarakat akan dapat menilai sejauh mana auditor telah bekerja sesuai dengan standar etika yang telah ditetapkan oleh profesinya. Kemudian Trisnaningsih (2017) mengatakan bahwa pemahaman good governance dapat meningkatkan kinerja auditor, jika auditor tersebut selama dalam pemeriksaan selalu menegakkan sikap independensi. 
Sehingga dapat dikatakan bahwa independensi mempengaruhi kinerja auditor.

Hasil penyebaran kuesioner maka diperoleh temuan empirik bahwa independensi tergolong tinggi, dimana dilihat dari independensi penyusunan program bahwa setiap pegawai memiliki kebebasan untuk menyusun program audit, kemudian dalam pelaksanaan penyusunan program audit yang dilakukan oleh tim auditor sudah terbebas dengan tekanan dengan pihak yang berkepentingan. Ditinjau dari independensi investigasi maka terlihat bahwa setiap pegawai tidak merasa tertekan dengan pihak yang berkepentingan saat melakukan investasi atas fraud, begitu pula bahwa setiap pegawai bersama dengan tim auditor bebas dari tekanan oleh pihak yang berkepentingan dalam melaukan investasi dalam kasus fraud.

Sedangkan ditinjau dari independensi pelaporan, terlihat bahwa setiap pegawai sudah bebas dari tekanan saat membuat Laporan Hasil Pemeriksaan (LHP), serta setiap pegawai menyampaikan laporan hasil pemeriksaan kepada atasan dan tidak tertekan oleh pihak lain. Hal ini dapat disimpulkan bahwa semakin tinggi independensi atau sifat kejujuran auditor, serta tidak mudah dipengaruhi dan tidak memihak kepentingan siapapun, maka kinerja auditor akan semakin meningkat, karena auditor tersebut melakukan pekerjaannya untuk kepentingan umum. Penelitian ini sejalan dengan penelitian yang dilakukan oleh Gita (2018) menunjukkan bahwa independensi berpengaruh positif dan signifikan terhadap kinerja auditor. Sedangkan penelitian Awaluddin (2013) menemukan bahwa independensi berpengaruh positif dan signifikan terhadap kinerja auditor, sehingga dapat dikatakan bahwa penelitian ini relevan dengan penelitian sebelumnya.

\section{KESIMPULAN DAN SARAN}

Hasil penelitian menyimpulkan bahwa kompetensi mempunyai pengaruh yang positif dan signifikan terhadap kinerja auditor pada Kantor Inspektorat Provinsi Sulawesi Barat. Hal ini dapat dikarenakan semakin tinggi kompetensi yang dimiliki melalui kemampuan dan pengalaman kerja yang dimiliki auditor, pelatihan yang diselenggarakan serta pengetahuan yang dimiliki auditor maka akan memberikan pengaruh terhadap peningkatan kinerja auditor. Komitmen Organisasi mempunyai pengaruh yang positif dan signifikan terhadap kinerja auditor pada Kantor Inspektorat Provinsi Sulawesi Barat. Hal ini mengindikasikan bahwa dengan adanya komitmen yang dimiliki oleh auditor dilihat dari komitmen afektif, komitmen kontinuans dan komitmen normatif maka akan setiap auditor akan semakin komitmen baik terhadap organisasi maupun terhadap pekerjaannya. Independensi mempunyai pengaruh yang positif dan signifikan terhadap kinerja auditor pada Kantor Inspektorat Provinsi Sulawesi Barat. Ini berarti bahwa semakin tinggi independensi yang dimiliki oleh setiap auditor melalui independensi penyusunan program, independensi investigasi, dan independensi pelaporan maka akan dapat memberikan hasil kerja auditor yang maksimal. Hasil pengujian serempak maka dapat disimpulkan bahwa kompetensi, komitmen organisasi, dan independensi mempunyai pengaruh secara serempak atau bersama-sama terhadap kinerja auditor pada Kantor Inspektorat Provinsi Sulawesi Barat. Ini menunjukkan bahwa dengan adanya kompetensi, komitmen organisasi dan independensi yang dimiliki oleh pegawai maka akan mempermudah dalam penyelesaian pekerjaan sebagai auditor. Dari hasil pengujian regresi maka diketahui bahwa variabel yang dominan berpengaruh terhadap kinerja auditor pada Kantor Inspektorat Provinsi Sulawesi Barat adalah komitmen organisasi. Ini berarti bahwa dengan adanya komitmen yang dimiliki dalam diri setiap auditor, baik itu komitmen atau kesetiaan terhadap organisasi tempatnya bekerja maupun komitmen terhadap pekerjaan maka akan mempengaruhi dalam pencapaian hasil kerja. Adapun saran-saran yang dapat diberikan agar perlunya auditor yang ada pada kantor Inspektorat Provinsi Sulawesi Barat untuk lebih meningkatkan pengetahuan yang dimiliki oleh auditor yakni dengan melakukan pelatihan-pelatihan terkait dengan bidang pekerjaan sebagai tenaga pemeriksa. Perlunya kantor Inspektorat Provinsi Sulawesi Barat untuk lebih meningkatkan komitmen dalam diri setiap auditor. Disarankan pula agar perlunya ditingkatkan lagi indenpendensi yang ada pada diri setiap pegawai yakni dengan melakukan investigasi dalam setiap kasus fraud.

\section{DAFTAR PUSTAKA}

Awaludin, Murtiadi. 2013. Pengaruh Independensi dan Kompetensi Auditor Terhadap Kepuasan Kerja dan Kinerja Auditor Inspektorat Kota Makassar. ASSETS Vol III/ 2 Thn 2013.

Bagia, I. W. (2015). Perilaku Organisasi Penerbit : Graha Ilmu, Yogyakarta

Busro, M. (2019). Teori-Teori Manajemen Sumber Daya Manusia. Penerbit : Prenada Media Grup. Jakarta

Edy Sujana (2012) Pengaruh Kompetensi, Motivasi, Kesesuaian Peran dan Komitmen Organisasi Terhadap Kinerja Auditor Internal Inspektorat Pemerintah Kabupaten (Studi pada Kantor Inspektorat Kabupaten Badung dan Buleleng) Jurnal Ilmiah Akuntansi dan Humanika Universitas Pendidikan Ganesha, Vol.2 No.1.

Ghozali Imam, 2018, Aplikasi Analisis Multivariate Dengan Program IBM SPSS 25, edisi kesembilan, cetakan kesembilan, Badan Penerbit : Universitas Diponegoro Semarang

Irma Istiariani (2018) Pengaruh Independensi, Profesionalisme, dan Kompetensi Terhadap Kinerja Auditor BPKP (Studi Kasus pada Auditor BPKP Jateng) Jurnal Islamida, Vol.9 No.1. ISSN :1412:477

Ningrum, F. K. (2017). Pengaruh Komitmen Organisasi, Motivasi, Kompetensi dan Gaya Kepemimpinan Terhadap Kinerja Auditor Pemerintah. Publikasi Ilmiah. 
Rismawati, \& Bachtiar, D. M. (2014). Pengaruh Kompetensi dan Independensi Terhadap Kinerja Pemerintah Kabupaten Luwu Timur. Jurnal Equilibrium, 4(02), 100-123.

Priansa, Donni Juni. 2014. Perencanaan dan Pengembangan Sumber Daya Manusia. Penerbit : Alfabeta, Bandung

Prawirosentono, Suyadi. 2017. Kinerja dan Motivasi Karyawan, Membangun Membangun Organisasi Kompetitif Era Perdagangan Bebas Dunia, edisi ketiga, cetakan kedua, Penerbit : BPFE, Yogyakarta

Purba, D.E. \& Seniati,A.N.L. 2011. Pengaruh Kepribadian dan Komitmen Organisasi Terhadap Organizational Citizenship Behavior. Makara, Sosial Humaniora, 8 (3), 105-111

Sangadji, Etta Mamang \& Sopiah. 2013. Metodologi Penelitian-Pendekatan Praktis dalam Penelitian, Penerbit : Andi, Yogyakarta

Saputra dan Yasa, Wirawan. 2013. Pengaruh Independensi, Profesionalisme, Tingkat Pendidikan dan Pengalaman Kerja pada Kinerja Auditor BPK RI Perwakilan Provinsi Bali. Jurnal Universitas Udayana.Bali.

Sedarmayanti, 2017, Perencanaan Dan Pengembangan Sumber Daya Manusia Untuk Meningkatkan Kompetensi, Kinerja dan Produktivitas Kerja, cetakan pertama, Penerbit : Refika Aditama, Bandung

Sujarweni Wiratna, V. 2016, Kupas Tuntas Penelitian Akuntansi dengan SPSS, Penerbit : Pustaka Baru Press, Yogyakarta

Sugiyono. 2016. Metode Penelitian Kuantitatif, Kualitatif, dan R\&D. Penerbit : Alfabeta, Bandung

Salju, Rismawati, \& Bachtiar, M. D. (2014). Pengaruh Kompetensi dan Independensi Terhadap Kinerja Auditor Pemeritah Kabupaten Luwu Timur. Jurnal Equilirium, 4(2), 100-123.

Sujana, E. (2012). Pengaruh Kompetensi, Motivasi, Kesesuaian Peran dan Komitmen Organisasi Terhadap Kinera Auditor Internal Inspektorat Pemerintah Kabupaten Badung dan Buleleng. Jurnal Ilmiah Akuntansi dan Humanika, 2(1).

Sutrisno, Edy. 2017. Manajemen Sumberdaya Manusia. Cetakan kesembilan, Penerbit : Kencana, Jakarta

Standar Profesional Akuntan Publik 2011 No. 1 tentang Standar Audit.

Sopiah. (2008). Perilaku Organisasi . Penerbit : Andi, Yogyakarta.

Suwatno dan Donni Juni Priansa 2014, Manajemen SDM dalam Organisasi Publik dan Bisnis, Penerbit Bandung: Bandung

Syafrizal Helmi Situmorang, 2011. Bisnis, analisis data, metode riset, Penerbit : USUpress, Medan

Trianingsih, Sri (2007), "Independensi Auditor Dan Komitmen Organisasi Sebagai Mediasi Pengaruh Pemahaman Good Governance, Gaya Kepemimpinan Dan Budaya Organisasi Terhadap
Kinerja Auditor", Jurnal Simposium Akuntasi Nasional, UNHAS Makasar.

Wibowo. 2014. Perilaku Dalam Organisasi. Edisi pertama, cetakan kedua, Penerbit : Rajawali Pers. Jakarta

Wibowo, 2016. Manajemen Kinerja, Edisi Kelima, Penerbit : Rajagrafindo Persada, Jakarta

Wibowo, 2017. Manajemen Kinerja (Kelima ed.). RajaGrafindo Persada. Jakarta

Wulandari dan Tjahyono. 2011. "Pengaruh Kompetensi, Independensi dan Komitmen Organisasi Terhadap Kinerja Auditor Pada BPKP Perwakilan DIY". Jurnal Bisnis dan Teknologi Informasi Vol 1 No. 1 Februari, 2011.

Yusuf, Burhanuddin. 2015. Manajemen Sumber Daya Manusia Penerbit : Raja Grafindo Persada, Jakarta

Yusniar Lubis, dkk. 2018. Manajemen Dan Riset Sumber Daya Manusia, cetakan pertama, Penerbit : Alfabeta, Bandung

Sutarjo, P. S. D. A., Cahyono, C., \& Saleh, H. (2021). Pengaruh Stres Kerja, Organizational Citizenship Behavior Dan Komitmen Organisasi Terhadap Kinerja Karyawan PT Japfa Comfeed Indonesia Tbk. Unit Corn Dryer Sidrap. Indonesian Journal of Business and Management, 2(2), 63-70. 